\title{
STOCK OPTION EXERCISE AND GIFT EXCHANGE RELATIONSHIPS: EVIDENCE FOR A LARGE US COMPANY
}

\author{
Peter Cappelli \\ Martin J. Conyon \\ Working Paper 16814 \\ http://www.nber.org/papers/w16814 \\ NATIONAL BUREAU OF ECONOMIC RESEARCH \\ 1050 Massachusetts Avenue \\ Cambridge, MA 02138 \\ February 2011
}

We are very grateful to the sample firm for granting access to the data used in this study. We also thank David Almeda, Iwan Barankay, Matthew Bidwell, Alex Edmonds, and Devon Pope for comments and suggestions. The views expressed herein are those of the authors and do not necessarily reflect the views of the National Bureau of Economic Research.

NBER working papers are circulated for discussion and comment purposes. They have not been peerreviewed or been subject to the review by the NBER Board of Directors that accompanies official NBER publications.

(C) 2011 by Peter Cappelli and Martin J. Conyon. All rights reserved. Short sections of text, not to exceed two paragraphs, may be quoted without explicit permission provided that full credit, including $\odot$ notice, is given to the source. 
Stock Option Exercise and Gift Exchange Relationships: Evidence for a Large US Company Peter Cappelli and Martin J. Conyon

NBER Working Paper No. 16814

February 2011

JEL No. J33

\begin{abstract}
$\underline{\text { ABSTRACT }}$
We investigate gift exchange relationships in real jobs, making use of a field quasi-experiment associated with the exercise of stock options for roughly 4500 managers in a large public company. In this company, option grants are set equally for all employees within occupational categories, and financial markets set the price at which the options are ultimately exercised. We assert that the considerable variation that we observe across employees and over time in profits from those sales is beyond the control of the individual employee and can be thought of as effectively randomized. We also assert that employees perceive the profit they receive from exercising these options at least in part as the equivalent of a gift: Higher profits in turn cause them to reciprocate with better job performance in the subsequent period. We find significant and economically meaningful positive relationships between the variation in profit per share of the options sold and standard measures of subsequent job performance for individual employees. These effects exist in real jobs and persist over long periods, extending previous studies. Non-parametric and parametric fixed effects models, other controls for sample heterogeneity, and alternative specifications address possible concerns about the randomization assumption and associated statistical issues.
\end{abstract}

Peter Cappelli

The Wharton School

Center for Human Resources

University of Pennsylvania

Philadelphia, PA 19104-6358

and NBER

cappelli@wharton.upenn.edu

Martin J. Conyon

Senior Fellow

Center for Human Resources

The Wharton School

University of Pennsylvania

Philadelphia, PA 19194-6358

conyon@wharton.upenn.edu 


\section{Introduction}

We make use of the field experiment associated with the sale of stock options for roughly 4500 managers in a large, publicly held US company to test gift exchange relationships. Option grants are set equally for all employees within occupational categories and do not vary with individual performance. All employees in the sample and during the period we observe have options and also have to exercise options, eliminating concerns about sample selectivity biases with respect to options received and exercised. The variation in profits from the exercise of options therefore is based on market prices at the time when individuals choose to exercise those options. Our interest is in observing the effects of the variation in profits across individuals on their subsequent job performance.

We assert, consistent with considerable research evidence, that the variation in share price and therefore the value of options is beyond the ability of individual employees to control or predict. The variation in profits we observe across individuals is determined by the variation in share price and is therefore essentially random. We then observe the effect of these profits on subsequent job performance. The field experiment comes from the fact that the treatment in this case, the variation in equity prices and profits from option exercises, is effectively randomized by financial market.

Employers here and in general claim credit for improvements in share prices, so we assert that employees in turn will attribute at least some of the credit for the size of the profits they earn to the employer. Therefore, we argue that employees will interpret these profits as the equivalent of a "gift" from the employer and will reciprocate accordingly. 
The context, described in more detail below, addresses several statistical problems that are otherwise vexing in studies like these. Our research extends a growing body of theoretical and laboratory research by studying a traditional employment context, where the original interest in gift exchanges began. We observe long-term effects, rule out otherwise confounding efficiency wage effects, and identify outcomes that are meaningful in practice.

\section{Research on Gifts and Gift Exchange}

The idea that gifts can be beneficial to those giving them has a long history, beginning in formal terms with Mauss' (1990 edition) anthropologically-based observations at the turn of the previous century concerning the role that gifts played in building relationships in primitive societies. Malinowski’s (1922) studies of ceremonial gifts in New Guinea established the idea that gifts served a fundamentally distinct function from the exchange of commodities, one that helped integrate individuals into communities and bound them together.

The focus on the obligations created by gifts and specifically on the concept of reciprocity came somewhat later, first in sociology (e.g., Becker 1956; Gouldner 1960) where researchers described the power of reciprocity norms and how they often contradicted the apparent self interest of those receiving the gifts (i.e., why reciprocate once the gift is received?). Reciprocity arguments came later to social psychology where at least initially the role of reciprocity was seen as difficult to separate from other mechanisms causing employees to do good, such as a sense of responsibility (e.g., Berkowitz and Daniels 1963). By the end of the 1960s, however, reciprocity became a 
central topic in the field of psychology and the subject of laboratory as well as field experiments (e.g., Pruitt 1968). The idea that gifts or offerings created an obligation to reciprocate or return the favor is now a standard component of psychology textbooks.

Reciprocity arguments have since been used in a wide range of settings to explain, for example, business practices in Silicon Valley, where a high proportion of business deals appear to be based around norms of reciprocity (Ferrary 2003) and organ transplants where recipients of transplants feel guilty that they cannot reciprocate the gift of the organ given by donors (who are often dead), especially if their own body rejects the organ (Sque and Payne, 1994).

The study of norms like reciprocity that appear to contradict at least short-term individual utility maximization came later to economics. The phenomenon that motivated Akerlof's (1982) seminal gift exchange argument was to explain why employers paid wages above market-clearing levels. Gift exchange models differ from efficiency wage and more traditional utility maximizing explanations in that the idea of a "gift" suggests that it is not required by the agent giving it, i.e., it is not part of a contract or something that is expected. Further, for a true gift exchange to operate, there should be no contractual arrangements or incentives at work to compel those receiving the gift to reciprocate.

Instead, the motivating factor in gift exchange arguments is the social norm to reciprocate. Research consistent with the general idea of social norms shaping behavior has been part of the experimental literature for some time (e.g., Kagel and Roth 1995 and List 2009 for a more recent review). And the experimental literature on gift exchange is 
now reasonably extensive. These include a series of studies by Fehr and colleagues (Fehr and Riedl 1993) who pioneered such experiments. Kranton (1996), demonstrates that gift exchange mechanisms can coexist with market exchanges, Hannan, Kagel, and Moser (2002) explore how differences in context and the attributes of subjects affect reciprocity responses, Maximiano et al. (2007), shows that gift exchanges can operate with groups, and Croson (2007) distinguishes reciprocity effects from related concepts like altruism.

As Charness et al. (2004b) find, gift exchange outcomes in laboratory settings can be reasonably sensitive to differences in context. That notion makes field research outside laboratory contexts especially important for external validity. Yet field studies of gift exchange have been limited. Falk (2007) finds gift exchange relationships in the field setting of charity donations, and most relevant here, Gneezy and List (2006) find these effects in the context of temporary jobs. They also find these effects diminish quickly, however, and that in terms of effect sizes, they are smaller than one might expect from spending the resources in other ways. ${ }^{1}$

Whether gift exchange relationships exist in more typical jobs, whether they persist over meaningful periods, and whether they are large enough to be seen as of practical importance remain open questions. To our knowledge, there is as yet no empirical gift exchange studies in traditional employment settings, the context which spawned the gift exchange idea.

\footnotetext{
${ }^{1}$ Fehr, Goette, and Zehnder 2009 provide an extensive overview of both the experimental and field research on research related to fairness in labor markets, of which gift exchange studies are one part. In related research, Lee and Rupp (2007) find that involuntary wage cuts, which could be interpreted as something like a negative gift, are associated with more flight delays in the airline industry. Edmonds (2010) finds that measures of employee job satisfaction can be thought of as an intangible asset that is associated with abnormal long-run returns to share prices, results that can be seen as consistent with gift exchange mechanisms.
} 
In the analysis below, we examine gift exchange relationships in the context of regular, long-term employment, a context that has great appeal for generalizability. We look at the exercise of stock options, a wide-spread compensation arrangement especially for white collar employees, and examine the effects on meaningful aspects of job performance. The experimental design allows us to sort out reciprocity effects from a range of possibly confounding effects.

\section{Analysis}

\section{A Quasi-Experimental Field Design}

We test the gift-exchange model using unique panel data from a single large, publicly traded US firm. Our specific hypothesis is that the greater the profit employees make through the sale of their stock options, the more they will perceive that they have received a gift and will therefore reciprocate in the next period with superior performance. The unique experimental design in this case is generated first by the fact that stock options are granted to employees without respect to job performance: Everyone at the same administrative level gets the same amount of shares with the same vesting and sales requirements each year. And all employees have to exercise options over the period we examine, so selection issues associated with receiving options and deciding to sell them are removed. The profits from the sale of options vary across employees solely based on the share price on the day the sale is executed. We assert (and provide evidence for this below) that employees cannot "time" equity markets, and therefore the differences in profits earned across employees is essentially random. We go on to use fixed effects estimation methods and other techniques that would be appropriate if the 
randomization assumption is not accurate to estimate the relationship between the profits per share earned on option sales - the gift - and subsequent job performance.

A reasonable question is why employees would see that profit as a gift from the employer. Charness (2004) demonstrates that attribution concerning why one receives a gift matters a great deal to subsequent responses: The more individuals see it as intentional and for their benefit, the greater the desire to reciprocate. (Although gifts that are not seen as intentional may still generate reciprocity norms, as Stanca 2010 finds.)

Employees in this case presumably know they will get some stock options when they sign up to work for the company, although how many is not known to them, and the value of those options is unknown. At best, one might reason that employees assign a Black-Scholes (1973) expected value to the options at the date of grant (although it is doubtful that the employees in our sample have the ability to do so). Even so, stock prices at the time the options can be exercised are likely to be perceived as something of a surprise as they vary considerably, a pleasant one if the price of the stock is high. But would they perceive that value as a gift coming from the employer?

The reason why it is sensible to think that employees would attribute at least some of the value of the profit from options as a gift from the employer is precisely because that is how employers represent it. They go to considerable lengths to persuade shareholders that improvements in share prices are attributable to the actions of the firm. They may blame declines in prices on outside factors, ${ }^{2}$ although it is only possible to sell options where share prices have risen above their exercise price in any case. The proxy

\footnotetext{
${ }^{2}$ The "negativity attribution bias" asserts that we attribute our success to internal factors and our failures to outside factors.
} 
statement, annual reports, and other communications from this company show, not surprisingly, that it attributes credit for its rising share price to the company's leadership team and strategy. In this context, it is not surprising that employees would attribute higher share prices to company performance and, in turn, to attributes of the company. ${ }^{3}$

Several studies have attempted to understand why organizations grant stock options to their employees, especially to non-executive employees, and whether there is anything unique about such companies. ${ }^{4}$ Because our study looks at the behavior of employees within a single firm who are covered by the same stock option plan, the empirical issue as to why this firm offers options is less important, although it may matter for making generalizations from the results. ${ }^{5}$

Randomization as Experimental Design: In a recent review, Angrist and Pischke (2010) argue that empirical work in economics has advanced greatly in recent years through improvements in research design, especially quasi-experiments that

\footnotetext{
${ }^{3}$ A sophisticated investor would discount share price increases associated with the market as a whole and even the industry sector and give the employer credit only for increases net of those effects. We cannot assess the extent to which any of the employees in our sample make such calculations, but the extent to which they do should weaken the size of the effects we observe.

${ }^{4}$ Core and Guay (2001) conclude that employers who do so face more difficulty in gaining finance, have a special need to retain employees, and need mutual monitoring of performance (i.e., where employers cannot easily monitor employee performance). Oyer and Schaefer (2005) conclude that firms have multiple reasons for giving employee stock: interest in retaining them, driving employee applicants to self select based on attributes like risk preference desirable to the firm, and constraints on ability to pay current salaries. Interestingly they find no evidence that incentives to motivate future job performance are at work.

${ }^{5}$ There is now an extensive empirical literature as to the performance effects associated with firms that have non-executive stock options as opposed to those that do not (e.g., Huddart 1994). Most recently, Hochberg and Lindsey (2010) see job performance effects but only in small firms where growth prospects are high. Our study, in contrast, looks at performance issues across and within employees in the same firm that are associated with the variations in payouts, as opposed to the presence of options per se.
} 
improve the ability to make inferences in observational data. Randomization lies behind arguably the best of these quasi-experiments. If done appropriately, randomization of the treatment variable ensures zero correlation with potentially confounding variables as well as eliminating the problem of endogeneity. Lee and Lemieux (2010), for example, assert that the heart of regression discontinuity research designs is the fact that observations just above and below a threshold cutoff score (e.g., students with grades just above and below the passing level) can be treated as effectively randomized. In our context, the fact that stock price variations are at a minimum unpredictable for individuals randomizes the treatment effect.

It is commonly assumed that randomization of treatment variables eliminates the need for control variables (because the correlation with treatment and control variables should be zero) and that mean differences between the treatment and control groups are sufficient to estimate causal effects. Leamer (2010) cautions that such a conclusion is inappropriate in field settings where asymptotic statistical properties are unlikely to hold, and for that reason we include controls in the analyses that follow. Therefore, we use fixed effects designs to address sample heterogeneity issues (see below).

Research Context and Data: We have unique information on managerial employees in a large, retail company in the S\&P 500 Index with over 50,000 employees in 47 US states. We have detailed information on the managerial employees in this company in the period 2001 to 2007, including information about their exercise of stock options and job performance. There were 12,365 person-year records and 4,569 individual-level records included in the input dataset. The lowest-level managers, also the most common job title in the data, are store managers. They represent over 98 
percent of the active individuals that were eligible to exercise equity received via the subject company's non-qualified (i.e., taxed as regular income) stock option program during this period. The most senior executives, designated as 16(b) officers, are excluded from this study along with foreign-based employees because their freedom to exercise stock options is restrained by law in ways that it is not for other employees. During the time period being examined, there was an average of five executives per year designated as 16 (b) officers in the subject company. ${ }^{6}$

The company policy on the granting of options to employees is noteworthy and critical to our research design. Non-qualified stock options were granted to managers based solely on their specific compensation grade level. The number of non-qualified stock options therefore did not vary within compensation grade level, nor did it vary with individual performance. ${ }^{7}$ The number of these options granted varied somewhat across year based on the company's situation and also varied by compensation grade. All employees in our sample receive options and all must eventually sell their options. Because every employee in our data has sold options, so decision to sell per se does not differentiate employees.

What does differ across employees is when they sell. Stock prices vary day-byday and therefore so does the profit employees make on their shares, which is completely

\footnotetext{
${ }^{6}$ SEC schedule 16(b) is intended to prevent the misuse of confidential corporate information by insiders. It imposes strict liability against corporate insiders (officers, directors, and greater than 10 percent shareholders) who buy and sell or sell and buy their company's securities within a six month period.

${ }^{7}$ The one caveat to this statement is that individuals who are good performers may be promoted into a higher compensation grade where they may receive more options. In that sense better performance is differentially related to options. We control for the grade one is in when they sell options. And the profits per share, our independent variable, are still independent of promotions and performance.
} 
determined by price on the day they sell. Crucial to our argument is the idea that the variations in profit per share that employees make is effectively beyond their control. We consider that assumption below.

Understanding what causes employees to sell options when they do is a relevant question and constitutes a separate research project in itself. Relatively little has been done in this area. Exceptions include a series of studies of such individuals that find, e.g., that stock price trends, which set references points, cause employees to sell (Heath, Huddart, and Lang 1999). More studies examine what the decision to sell might reveal about future firm performance, getting at the question as to whether employee selling decisions are driven by their ability to time the market. The results of these studies are conflicting: A positive relationship (Huddart and Lang 1996), no relationship with more recent data (Core and Guay 2001), and a positive relationship before 1991 but only in small firms after (Carpenter and Remmers 2001). Note, however, that all employees in our sample have to sell options.

Because our interest is in seeing how the outcome of option sales affects subsequent job performance, it raises the obvious concern about establishing causation in the relationship between performance and the profits from exercising options: Employees differ in when they sell options, and something is driving those decisions. A possible issue of endogeneity occurs if employee performance could actually drive share prices and option profits. Specifically, because the data we have are longitudinal, the issue would be if job performance in period $t$ is correlated with performance in period $t+1$ such that it creates the appearance that higher share prices in $t$ are driving higher performance in $t+1$. Top executive job performance could reasonably change share prices, but such 
executives are excluded from the analysis here. Ninety-eight percent of the individuals in our sample are store managers, and it is highly unlikely that the job performance of any individual employee at this level could have any noticeable effect on share prices of the company as a whole (the company certainly believes that collectively employee performance can affect share price).

A more credible concern is that if better performing employees were able to make higher profits by selling options at points where stock prices were higher (or lower performing employees sold when stocks were lower), then the relationships we observe would be confounded by omitted variable problems. ${ }^{8}$

A potential solution to these estimation problems comes from the contemporary idea, supported both by theoretical and empirical evidence, that the movement of share prices is so difficult to predict that we can think of that movement as essentially random. If that is the case, then profits from options sales are essentially random as well. Then both the endogeneity and omitted variable problems above are moot: Job performance cannot drive net profits from exercising options; nor can unobserved variables like individual ability have such influence because profits from option exercises are beyond the control of the individual to influence.

The idea that individual equity prices move in a way that is random dates from Samuelson (1973) and was popularized by Malkiel (1996 edition). The idea that equity markets are efficient, a stronger claim, goes back in contemporary terms at least to Fama (1970, 1997, reaffirmed by Fama and French in 2010). More observers believe that

\footnotetext{
${ }^{8}$ If the reverse was true and good performers made less money or poor performers more, it would bias the relationship downward and make it more difficult to confirm the hypothesis.
} 
financial markets are "weakly" efficient in the sense that publicly-held share prices incorporate the relevant information that is available to the public. There have been a number of critiques even of the weak view of efficient financial markets. For the most part, these have to do with imperfections in overall equity markets that cause certain shares to be systematically under-priced (e.g., the four-factor model) rather than whether the variations in price for a particular company stock are predictable. And the extent to which equity prices are appropriate reflections of the future value of a company or merely internally consistent representations of value across firms remains up for debate.

Our argument requires far less than the even the weak form of efficient markets, however. It simply requires that the variation in equity prices be effectively impossible for the average investor to predict in advance. More specifically, our claim is that individual investors of the kind who make up the manager base in this company cannot time the market in terms of knowing when the value of their company's shares is at or near its top value. (The fact that option sales here not instantaneous as it takes time to execute them adds to the difficulty in timing the market.) To our knowledge, there are no credible arguments suggesting that a typical investor could "time the market" in the relevant sense of generating abnormal returns by knowing when to sell options on a particular stock.

Inside information not available to a typical investor might make it possible to make abnormal profits because such information is not available to the market. Employee investors of the kind we examine here may have access to such insider information. In practice, the evidence on the selling decisions of corporate insiders suggests that they do 
not in fact earn abnormal returns from the sale of their company's stock (Lakonishok and Lee 2001). While managers assess the value of their company's shares in ways that are systematically different from the market's assessment, those assessments do not lead them to profit abnormally from those assessments (see Jenter 2005). Further, executives have been shown to make basic mistakes in their decisions to sell company stock (Malmendier and Tate 2005).

The access to information that store managers of the kind we focus on here have is much more limited than what executives have in the above studies. The limited evidence on non-executives suggests that they do not earn abnormal returns on selling their employer's stock, either. Bergman and Jenter (2007), find, for example, that nonexecutive employees are overly optimistic about the future value of their employer's share price, and companies are able to grant options in exchange for lower salary when they are overvalued. Lambert and Larcker’s (2001) survey of individual employees finds them largely ignorant about the value of their stock options. For example, 11 percent allowed "in the money" options to expire without being exercised.

To the extent that the employees we examine have any inside information that could affect their ability to time sales in order to maximize profit, we argue that such information is likely to be common to everyone in a pay or administrative grade. When we control for pay grade, therefore, we should effectively control for any effects associated with such inside information. As discussed at length below, if there was an ability for insiders to influence share price, that effect would only matter for our results if that ability was correlated with job performance in subsequent periods. 
Even though investors may not be able to beat the market, there is considerable research suggesting that some investors may systematically lose value when trading because of cognitive biases or other decision heuristics that cause them to depart from rationality. Such investors have been defined as "noise” traders (Shleifer and Summers 1990) because they make decisions based on factors that are not relevant to future share prices. If noise traders also turned out to be poor performers - specifically, if an unobserved factor contributed to both - then we might see an association between profits from option sales and job performance that was spurious. ${ }^{9}$

There are many studies of cognitive biases and systematic irrationality that could in principle lead to below average profits from investment decisions (see, e.g., Barber, Odeon, and Zhu. 2009). Those that are relevant here concern only selling decisions because these employees do not make buying decisions. The studies investigating selling mistakes suggest that they are driven by simple heuristics such as whether share prices have been declining (e.g., Benartzi and Thaler, 2001). While some of these heuristics may lead to below average profits, there is no evidence that using such heuristic-based decisions are or should be associated with below average job performance. While there is evidence that being "smarter" causes better job performance, there is no credible evidence that being smarter, at least as defined by traditional measures, leads to better stock market performance. For example, while we might imagine that individual investors who made the switch to online trading sooner than their peers would be those

\footnotetext{
${ }^{9}$ Note that if noise traders lose money because of their poor trading and then performed poorly because of the loss, that would be consistent with our general gift exchange story as long as they blamed the company rather than themselves for the loss.
} 
who are more savvy and that they therefore should have better trading outcomes, the reverse turns out to be true (Barber and Odeon 2002).

The fact that there is no evidence of any factor that both causes employee investors to do relatively better (worse) at timing the sale of their options and that also improves (hurts) their job performance does not rule out the possibility that such a factor exists, of course, given that this has not been a topic of investigation. As described in more detail below, we use panel data that allows us to calculate fixed effects models within individuals to address this and related concerns. Any dispositional factors that affect both job performance and option selling performance should be controlled for in fixed effects models.

It is also conceivable that a relationship between profits from options and subsequent job performance might operate through channels other than gift exchange. One such channel might be if those who made greater profits used those funds in ways that improved their job performance, such as investing in their own skills or dealing with life problems that interfered with their work.

There is no direct evidence on the extent to which employees make such investments, and there is considerable evidence that the reverse is generally true: Income perceived as a windfall, such as unexpected payments (Arkes et al 1994) or lottery winnings (O’Curry and Gneezy 2007) is spent frivolously (see more generally Eply and Ayelet 2007). Further, we know that if leisure is a normal good, income effects associated with greater income or wealth lead to increases in leisure and a reduction in market-based work. This is also true within household work decisions (Gronau 1977). 
The idea that individuals would be less motivated to work hard when they receive greater income is also consistent with multiplicative (as opposed to linear) preferences in utility functions, an assumption common in other studies (see, e.g., Edmans, Gabaix, and Landier 2010). We might therefore expect an individual who receives unexpected option profits to be less motivated to work hard in pursuit of a good performance appraisal score and, in turn, a larger merit pay increase or bonus, making for a more conservative test of our hypothesis.

The Incentives Hypothesis: A different hypothesis concerning options and job performance that does not necessarily compete with the above is arguably the traditional view that options create incentives for employees to work hard to improve firm performance and, in turn, the value of their own holdings. For lower-level employees, the connection between their individual efforts and share price is imperceptible at best, so working harder in an effort to raise share price is not necessarily a rational response. But the perception that there is such a link is clearly cultivated by employers, and employees may well respond to such suggestions. For this hypothesis, holding options rather than selling them is what matters to subsequent job performance as the more one holds, the greater the apparent incentives to performance and drive share prices higher.

We can test this model in our analyses. We know the number of options each individual holds in their account, and we can see how this level relates to subsequent performance measures. Note that it is possible for both hypotheses to be true: Holding options yet to be exercised may motivate employees to work harder through a perceived 
incentive mechanism, and exercising more profitable options may also cause employees to work harder through the mechanism of reciprocity. ${ }^{10}$

\section{Variables}

The general gift exchange hypothesis predicts that individuals who receive a gift will reciprocate. In the context of an employment relationship, employees who perceive that they have received a gift from the employer will reciprocate in the employment context, by behaving in ways that advance the interests of the employer. Gift exchange per se provides no guidance as to the exact form that the reciprocity will take except for the general idea of benefiting the employer. Given that, the ideal measure would include all aspects of employee job performance relevant to the employer. The measure we use is each employee's annual performance appraisal score, a standard measure of individual performance based on the job requirements for each position. Because it is the employer's own measure, it is the best assessment of performance in the job that matters to the employer.

As with many other companies, this firm measures employee performance using Likert-type rating scales, in this case using a scale 0 (poor performance) to 4.00 (excellent performance) with the ability to differentiate in 0.01 increments. Conceptually, therefore, it is a 400-point scale, although in practice not every supervisor calculated performance at the level of two decimal points. The score itself is based on six items associated with financial outcomes (e.g., sales/budget for store managers) and four items associated with more subjective aspects of individual (e.g., ability to work with other

\footnotetext{
${ }^{10}$ The number of options held is also a proxy for employee wealth, and greater wealth should allow for more patient investment decisions. As noted above, wealth effects should have the opposite effect on job performance, lowering motivation to work hard.
} 
employees). Only the overall score is retained by the company, and we only have access to that score.

For purposes of robustness, we also examine another measure of employee performance, dismissals for performance-related problems. Being fired for poor performance is obviously a very clear indicator of poor performance, although it has the drawback of not differentiating performance above that dismissal threshold. This second outcome variable is an indicator (yes $=1$ or no $=0$ ) of whether or not the employee was dismissed by the company because of performance-related issues.

The main independent variable is "option profits". We proxy the firm's gift to the employee as the option gain received by the seller. This is defined as the value gained by the employee when exercising the option. The value received is calculated by deducting the non-qualified stock option grant (exercise) price from the stock price at exercise for every option exercised during a person-year. The result was then aggregated across all exercises in the year. The average profit gained per share is the total gain divided by the total number of non-qualified options exercised during a given person-year.

The estimated models contain a number of control variables. These are: Employee Level: the hierarchical level of a manager in the organization during each person-year. Medical: an indicator variable (yes or no) of whether or not an executive is enrolled in the company's health benefits plan, which may capture aspects of risk tolerance as well as health issues that could affect performance. Age: the average age of an executive during a specific person year. Male / Female: a dummy variable indicating the executive's gender. We use two variables to control for compensation differences. Salary 
is defined as the employee's base salary during the year, which may vary within job title because of merit/performance-based increases. Bonus is the employee's annual bonus received during each year, which also varies based on prior performance.

We know the amount of vested stock in each employee's portfolio that they continue to hold. This is defined as the remainder after exercise of options: i.e. the percentage of total vested stock in a specific executive's E*Trade account that an executive exercised during a specific person year. If we think that options create an incentive for better performance, we should expect to see a positive relationship between the amount of stock held and subsequent performance measures. We use this variable to test for the incentives hypothesis.

\section{Results}

\section{Non-parametric results for Gift Exchange}

Descriptive statistics for the individuals at the sample firm are contained in Table 1. The mean base salary is about $\$ 67,000$ over the period 2001 to 2007 , which reflects the fact that these jobs on average are relatively low-level managerial roles. The average bonus is about $\$ 7,700$ dollars, so the typical manager gets about a $12 \%$ bonus. The mean profit from an average sale is about $\$ 30,000$, a sizeable sum equivalent to around $40 \%$ of annual pay in the year when sales are exercised. ${ }^{11}$ The typical number of shares sold

\footnotetext{
${ }^{11}$ With this amount of profit relative to salary income, one might wonder whether there are wealth effects in addition to gift exchange relationships. Wealth effects run in the opposite direction: Wealth causes one to be less dependent on wage income and, as with substitution effects, should cause employees to think about consuming more leisure and arguably work less hard at their job. We might therefore expect them to pay less attention to job performance, other things equal, when they have profits from option sales.
} 
from the pool of vested stock is about 1000 . The employee holds about $40 \%$ of vested stock after a sale of options.

The mean employee rating is about 2.8 and positively skewed, as illustrated in the figure 1. This skew is common in performance appraisal scores and may be attributable to the unwillingness of supervisors to give low scores. Because the data are skewed, the regressions use the log of employee performance (the results are generally robust to this monotonic transformation). Mean tenure of employees in the sample is 4.7 years, average age is about 40 , and roughly 80 percent of employees receive medical benefits from the employer. (The employees have an option to receive cash compensation instead of medical benefits, and those who take that option have other sources for medical coverage, typically a spouse’s plan.) About 36 percent of the employees are female, 5 percent are black, 4 percent are Asian, and 4 percent are Hispanic.

Non-parametric estimates of the probability density function of the job performance evaluation variable are presented in Figure 1. The Epanechnikov kernel function is used to estimate the density. All the employees in the data set exercise their stock options at least once in the period from 2001 to 2007. The one dimensional kernel densities are drawn for two sets of employees: those who sold in the prior period made less than \$6 per share and those who sold last period and made more than $\$ 10$ per share. These cut-offs represent approximately the 25th and 75th percentiles of the profit per share distribution. The mass of the distribution for employees receiving greater profit per share last period lies to the right of employees enjoying less profit. The figure illustrates our basic hypothesis, that greater profit from options sales is associated with better job 
performance. The parametric regressions below show this is robust to the inclusion of controls.

\section{Econometric results}

For purposes of robustness, we begin with simple wage regressions for employees to see whether the data produce reasonable relationships. Table 2 contains estimates from a standard wage equation. The dependent variable is the log of the base salary for employee $\mathrm{i}$ at time period t. The model includes employee performance evaluations (indicator of employee effort), employee age, employee medical coverage, compensation grade levels, and a set of demographic variables (sex and race). The models are estimated using random effects estimators (odd numbered columns) and fixed effects estimators (even numbered columns).

The estimated models confirm a positive correlation between wages and employee effort levels. There is a significantly positive correlation between pay (however measured) and employee rating in all models, estimated either using a random effects panel data estimator or panel data fixed effects estimator. The fixed effects in this case are person fixed effects. The models are estimated over the period 2001 to 2007. The current model includes contemporaneously dated pay and performance evaluation. This restriction is not required to establish the statistical result. In results not reported, we find a positive correlation between current levels of pay dated at time $t$ and previous levels of performance ratings at time $\mathrm{t}-1 .{ }^{12}$

\footnotetext{
${ }^{12}$ In un-tabulated results we find the relationship between executive wages and pay grade level is convex (non-linear). This means that pay increases at an increasing rate as an employee moves through the pay grades. This is consistent with tournament theories of compensation. In
} 
Figure 2 contains a simple linear regression of log employee rating in $t+1$ on the log of profit per share of options exercised in t. There is a statistically positive correlation between the two, suggesting that a greater gift today may alter employee behavior leading to greater employee performance in the next period. The next step is to see if the basic data are robust to statistical control variables.

Table 3 examines the gift exchange hypothesis in a regression format. The dependent variable in the regression is the log of subsequent employee performance, i.e. the employee rating of employee $i$ at time period $t+1$. Recall that the employee performance rating ranges from a low value of zero to a high value of 4.00 . The log transformation is used because of the right-skew in the employee rating data (see Figure 1). The main independent variable of interest is the value (cash) received from selling the options given by the firm. The log of the variable is used to mitigate outlier influences. ${ }^{13}$ The table shows estimates of the relation between the employee's gain from exercising stock options this period and the subsequent employee performance appraisal score in $t+1$. The option gain is a proxy for the firm's 'gift' to the employee.

There is a positive relationship between future effort (employee rating) and the profit per share received today (gift exchange), consistent with our main hypothesis. The control variable salary plus bonus is positively related to subsequent employee performance ratings, consistent with an efficiency wage relationship: High paid

tournament models, increasing levels of pay are required to motivate employees whose options to proceed to the next round of the tournament are diminishing.

${ }^{13}$ The results reported below are generally robust to whether we use the log of profit per share or the untransformed version. The transformation permits estimation of a log-log model. 
employees increase their effort as reflected by employee performance. ${ }^{14}$ The gift exchange relationship exists independent from efficiency wage effects associated with compensation levels.

The model also allows us to test for incentive effects. We find a positive relationship here as well: The more options the employee holds, the better their job performance is in the subsequent period. The gift-exchange effect persists, though, along with the incentive effect.

Random effects cannot control for unobserved differences in individual attributes. Even though there is no prior evidence that it should be the case, sample heterogeneity in the form of unobserved personal attributes could possibly contribute to both performance levels and selling decisions that affect profit levels. Specifically, would better (worse) individuals somehow perform better (worse) in their jobs and better (worse) at exercising their options?

Again, if one believes that the treatment effect is randomly distributed, these concerns are moot. But we address them in an additional way with fixed effects estimation that look at option sales and job performance within individuals over time. When we control for individual employee fixed effects in Column 2, the positive relationship between employee performance rating at $\mathrm{t}+1$ and current profits per share (gift) at t remains. In fact, while the coefficients for salary and stock options fall in size by roughly half with the fixed effects estimation, the gift exchange coefficient roughly doubles in magnitude. It is considerably bigger than the incentive effect, by a factor of

\footnotetext{
${ }^{14}$ In un-tabulated results we included the lagged dependent variable in the regression model to see whether the salary effect was due to persistence in performance. The salary variable remained significant.
} 
almost seven times. This suggests that otherwise unobserved sample heterogeneity at the individual employee level had been diminishing the gift exchange effect. ${ }^{15}$ It also suggests more generally that cross-sectional estimates of gift exchange relationships may not be appropriate.

These estimates also contain controls for time effects. If, for example, a downturn in company performance caused "noise trader" employees to sell their options and lose (relatively) on them and also caused some overall lowering of individual performance (e.g., if morale fell), such effects should be captured and controlled by time variables. In analyses not reported in the tables, we test this specific idea by examining the relationships when excluding individuals who sold their options in the largest downturn in share prices, effectively excluding the "noisiest” traders. The overall relationships were unchanged.

A final estimation issue concerns the fact that the outcome variable is constrained to lie between zero and four. These bounds may mean that the previous estimators lead to biased coefficients. Column three contains the results from estimating a two-sided Tobit model with random effects. Again, a statistically positive relationship between employee effort and profit per share persists.

\section{Job separation regressions for poor performance}

\footnotetext{
${ }^{15}$ For example, it could be that personality differences across individuals cause some to feel a greater sense of obligation than others. Such unobserved differences might reduce cross-sectional relationships and are controlled for with the within-individual estimates of fixed effects models.
} 
Table 4 reports estimates of the relation between future performance-related job separation at $\mathrm{t}+1$ and gift exchange. ${ }^{16}$ The data allow us to identify all employees who are terminated for performance reasons among those who receive stock options. The hypothesis is that employees who receive a gift, again measured by greater profits per share, will be better performers and less likely to exhibit the poor performance that leads to termination. Poor performance is defined by the company as: Refused to perform job duties, Violation of company policy, Insubordination, Inability to perform job, Cash shortages, Falsification, Disciplinary action-suspension, Fraud, Theft etc.

The results show that the likelihood of being fired for poor performance is less the greater the profit per share received from the sale of options in the previous period, other things equal. As before, the results are robust to efficiency wage explanations. Employees with high wages (efficiency wage) are also less likely to be fired for poor performance, but the gift exchange effect exists separately from that relationship. Also the models control for incentive effects - the more options the employee holds the less likely he or she is to be terminated for poor performance. The gift-exchange effect persists when controlling for these other relationships as well.

In addition to statistical significance, it is useful to ask whether the gift exchange effects we observe are economically meaningful. With respect to the job performance measures, the $\log$ on log estimates suggest that a doubling of stock price, which is equivalent to a doubling of profits per share, is associated with a 1.3 percent increase in

\footnotetext{
${ }^{16}$ In un-tabulated results we investigated the correlation between voluntary turnover and profit per share. Here the idea is that employees receiving a gift are less likely to quit. The results (sign) were qualitatively similar, though the statistical significance was reduced.
} 
the job performance scale and a 1.1 percent reduction in performance-related dismissals. Estimating the value of the latter may be more straight-forward: The full compensation cost with benefits of an average employee in the sample is roughly $\$ 100,000$ per year. Estimates of typical turnover costs are the equivalent of a year or more of compensation, a figure that could be higher for dismissals, which drive legal challenges. A doubling of profits per share therefore saves the company about \$1100 in expected termination costs per employee. Given that profits per share varied in the sample from $\$ .25$ to over $\$ 20$ and the distribution had a standard deviation of $\$ 3.4$ around a mean of $\$ 8.4$, doubling the profits one could receive over time would not be an unusual event.

Estimating the value of improved job performance is less straight-forward. An improvement of 1.3 percent in a performance appraisal score may not sound like much. It is difficult to calculate the value generated by an individual employee and the differences in that value associated with various performance score. But as the distribution of such scores in Figure 1 shows, even a small increase around the mean score may change one's rank relative to other employees considerably. Many employers make considerable efforts to sustain even small improvements in job performance.

Perhaps more to the point, gift exchange effects in these estimates seem much more powerful and efficient than incentive effects, interesting because the latter typically form the rationale for stock options. It would take roughly a seven-fold increase in the amount of options held to generate the same job performance effects as a doubling of profits (i.e., the effects on performance are equal). Depending on how the accounting is done (i.e., whether options are expensed), the increase in options held could be quite 
costly to the employer while the doubling of profit on those options could cost the company nothing. ${ }^{17}$

\section{Robustness checks}

In this section we explore alternative evidence for some of the results above. The first exercise examines further whether individual employees can influence the profitability from the sale of their option shares, whether they can essentially time the market. If they cannot, as we assert above because efficient equity markets randomize share price movements, then it is not possible for job performance to drive profit outcomes or for omitted variables to be driving both profit outcomes and job performance. We test this assertion by looking at the profit per share made by an individual today and correlating this with profit per share made previously (i.e., the autocorrelation in the distribution of profits per share made by individuals) to see if some individuals consistently do better at selling their options.

The results are contained in Table 5 . We estimated a simple linear regression model, $y(t)=a+b y(t-1)+e(t)$ for each employee separately in the database. The term $y$ is profit per share and 'b' is an estimate of the relation between profit from options received by the employee this period and profits the last time the employee sold options. In the panel data the time marker ' $\mathrm{t}$ ' is quite short, so we estimated the model only for individuals with more than 4 observations. Although somewhat crude due to the limited of time-series data, we find that profitability is uncorrelated over time by individual. The data shows little evidence of autocorrelation. In other words, individuals do not appear to

\footnotetext{
${ }^{17}$ This assertion may not be strictly true, of course, if there are costs associated with getting the company in a position where share prices double.
} 
be able to "time" option sales to affect their profits. This result supports the notion that profits per share are random from the perspective of the individual. There is variation in the estimated correlation of option profits over time in the overall sample, but even there the mean (median) values are low and generally not significant.

The second exercise addresses the endogeneity concern in a different way: Do we find a relationship between job performance in period $t$ and profits per share in $t+1$ ? For whatever reason, could causation run the other way? We reverse the previously estimated model and regress job performance in period 1 on profits per share in $t+1$, reporting the results in the Table 6, and find no relationship. In fact, the sign is in the wrong direction, further corroborating our main results.

The third exercise takes a different approach to these concerns by attempting to find situations where the exercise of options is involuntary. The idea here is to address the concern that because employees decide when to exercise their shares, they have at least the possibility to influence the profits from those sales. (Again, this concern is moot if we believe that equity markets are efficient.) If they could influence their profit, then the door is open to endogeneity and omitted variable problems.

If employees have to exercise their options, on the other hand, then their ability to time sales to improve profitability goes away. The possibility that an omitted variable is driving profitability and sales becomes moot as does the possibility that job performance could be driving profits per share, even if one believes that equity markets are not efficient and that employees could "time" the market. 
It may not be possible to identify precise situations where employees have to exercise their options within these data, but we can look at periods where there are additional incentives and pressures that cause them to exercise options. If the relationship between profits per share in period $t$ and job performance in period $t+1$ persists even in these circumstances, then we have even greater confidence in the results. One of these periods occurred with a change of CEO in the company in 2006. Such transitions may be associated with uncertainty as they may portend a change in strategy, restructuring that could lead to job losses, and other changes that may affect future profitability and one's continued employment. Efficient market explanations suggest that all such uncertainties are already incorporated in equity prices, but this exercise is designed to address concerns if that view is incorrect.

We examine the above model in the transition year when the old CEO was departing and the new one took over, the period of maximum uncertainty. Namely, we repeat the regression analysis for the years 2006 only. One concern about restricting the sample this way is that the sharp reduction in observations may make it more difficult to find significant relationships. We report the results in Table 7 (Column 1), where we find that the relationship between profits per share and subsequent job performance persists.

We repeat this exercise in another context: Employees who are leaving the firm. Employees must exercise their stock options within three months of exiting the firm. (Note that this requirement also addresses efficiency wage concerns as employees do not have to keep their jobs to exercise their options.) Those employees who are retiring know well in advance that their exit is coming; those who are quitting voluntarily know as well, although arguably not as far in advance as retirees as to when the exact exit date will be; 
even those who are terminated may have a strong sense that their exit is coming. In companies like these, employees are rarely fired without significant warnings that include “performance improvement plans” and other remediation efforts.

In this last exercise, then, we begin by identifying those individual who exited the company. We examine their final performance appraisal score before leaving the company and the profitability of any options exercised in the period immediately before that. These results are also presented in Table 7 (Column 2). Despite the smaller sample, the relationship between option profits and job performance is significant and indeed larger in magnitude than those for the entire sample.

\section{Conclusions}

Evidence of reciprocity that forms the basis of gift exchange relationships has been wellestablished in experimental contexts. Evidence in field settings has been much less common, and prior results raise questions both as to whether gift exchange effects persist and whether they are large enough to be meaningful. The results above examine gift effects in employment relationships, a context that is of considerable practical significant and which spawned the gift exchange idea in economics. We find reciprocity effects in the form of two important measures of job performance. Those effects operate over the course of one year, suggesting a much higher level of persistence than in previous experimental studies.

How to assess the cost of the gift in this case is an interesting question. The initial grant of the stock options has a cost to the employer, but the increase in profits associated with rising share prices do not. The value of the exchange in this case - the better 
employee performance - certainly seems to be worthwhile for the employer. The fact that gift exchange effects are considerably more powerful than incentive effects in our job performance estimates is an important conclusion.

In subsequent research, it would be useful to study further the possible responses to various option sales-related events. For example, do we see different, arguably negative, gift effect relationships when profits per share have fallen from recent higher levels; do we see something similar when prices rise after options were exercised. It would also be interesting to see whether these gift exchange effects exist or perhaps vary across other aspects of job performance, such as cooperative behaviors or good citizen behavior that is harder to observe. 
Figure 1: Kernel density estimates of performance appraisal score evaluation

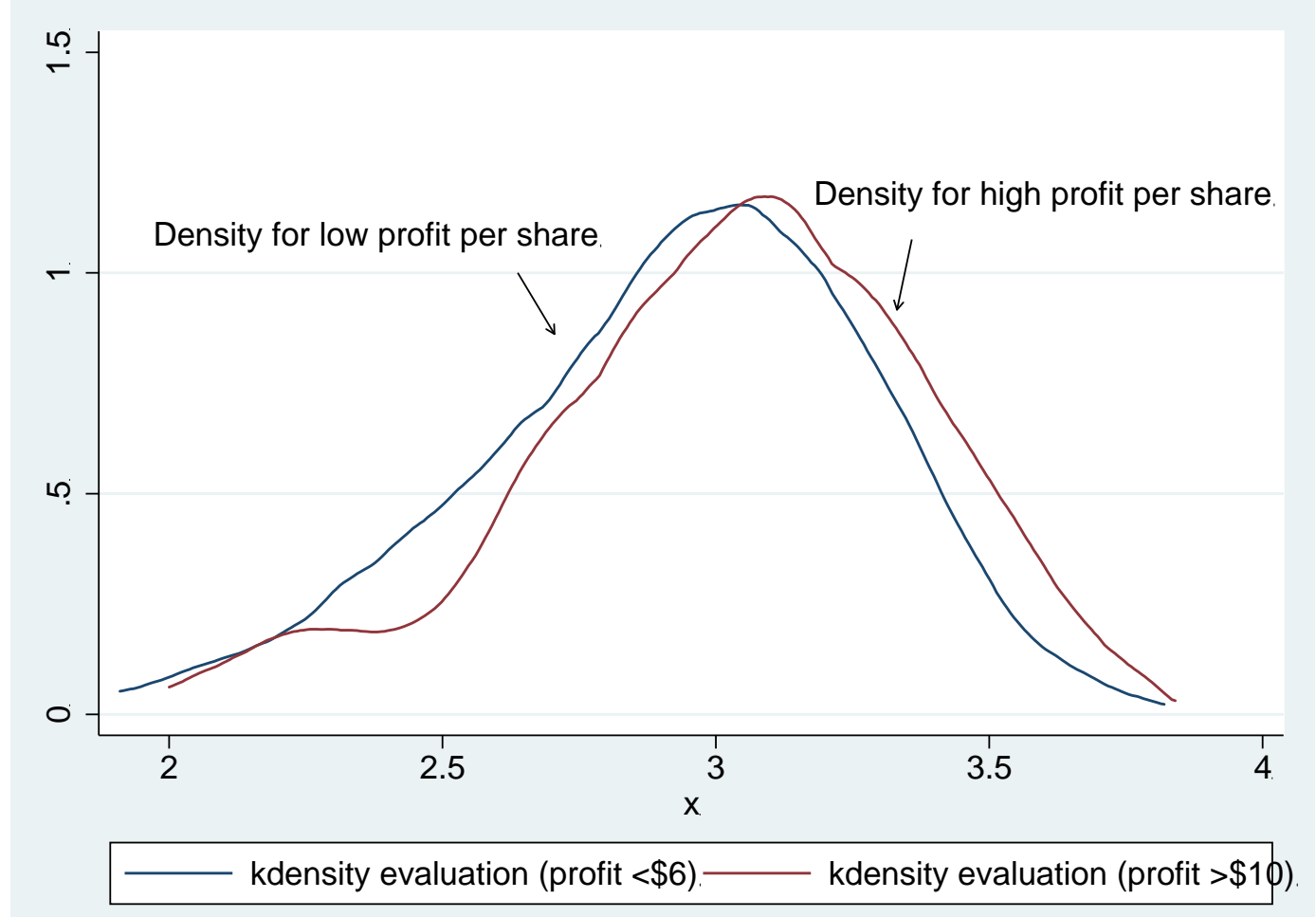

Notes:

Kernel density estimates presented of the employees job performance evaluation (0-4 range). All employees in the data set sell some options. The one dimensional kernel densities are drawn for two sets of employees: those who sold in the prior period made less than \$6 per share and those who sold last period and made more than \$10 per share. These cut-offs represent approximately the $25^{\text {th }}$ and $75^{\text {th }}$ percentiles of the profit per share distribution. 
Figure 2: Employee performance and profit per share

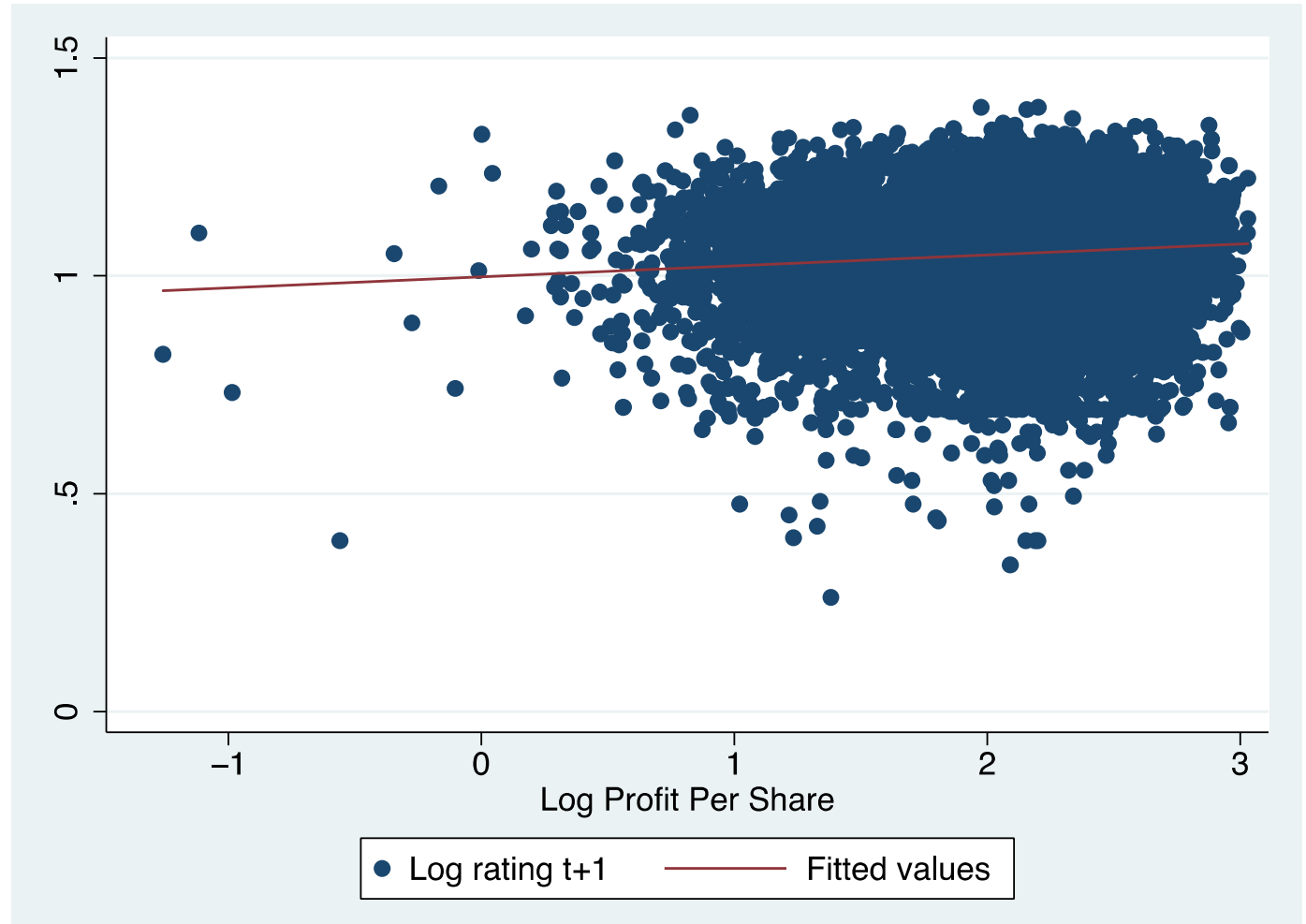

Notes:

Based on large publicly traded US firm. The y-scale is log of future employee rating; the $\mathrm{X}$-scale - log profit per share. $\mathrm{N}=9386$ person-year observations over time period 2001 to 2007 
Table 1: Descriptive statistics

\begin{tabular}{llllll}
\hline Variable & Mean & sd & p25 & p50 & p75 \\
& & & & & \\
Salary (\$) & 67328.40 & 32132.93 & 48400.19 & 61250.04 & 77443.34 \\
Bonus (\$) & 7434.71 & 13725.10 & 0.00 & 2994.72 & 9959.14 \\
Profit (\$) & 29171.25 & 73899.78 & 5446.15 & 12132.57 & 26916.12 \\
Profit per share (\$) & 8.43 & 3.74 & 5.64 & 8.13 & 10.72 \\
Number exercised (\#) & 961.41 & 4106.90 & 0.00 & 0.00 & 579.00 \\
Percent options owned (\%) & 39.88 & 31.89 & 5.98 & 38.70 & 68.93 \\
Employee rating (0-4 scale) & 2.82 & 0.39 & 2.56 & 2.85 & 3.10 \\
Job separation for poor performance & 0.04 & 0.19 & 0.00 & 0.00 & 0.00 \\
(0-1) & & & & & \\
Tenure (Years) & 4.77 & 2.17 & 3.00 & 5.00 & 7.00 \\
Age (Years) & 39.91 & 9.05 & 33.00 & 39.00 & 46.00 \\
Medical coverage (1=Yes) & 0.81 & 0.39 & 1.00 & 1.00 & 1.00 \\
Female & 0.36 & 0.48 & 0.00 & 0.00 & 1.00 \\
Black & 0.05 & 0.22 & 0.00 & 0.00 & 0.00 \\
Asian & 0.04 & 0.20 & 0.00 & 0.00 & 0.00 \\
Hispanic & 0.04 & 0.19 & 0.00 & 0.00 & 0.00 \\
& & & & & \\
\hline
\end{tabular}

Notes:

The mean, standard deviation (sd), $25^{\text {th }}(\mathrm{p} 25)$; median (p50) and $75^{\text {th }}(\mathrm{p} 75)$ percentiles are reported. 
Table 2: Wage Regressions

\begin{tabular}{|c|c|c|c|c|}
\hline & Log (salary) & $\begin{array}{l}\text { Log (salary } \\
\text { plus bonus) }\end{array}$ & Log (salary) & $\begin{array}{l}\text { Log (salary } \\
\text { plus bonus) }\end{array}$ \\
\hline & $\begin{array}{l}\text { Random } \\
\text { effects }\end{array}$ & $\begin{array}{l}\text { Random } \\
\text { effects }\end{array}$ & Fixed effects & Fixed effects \\
\hline Employee rating & $\begin{array}{l}0.016^{* * * *} \\
(0.001)\end{array}$ & $\begin{array}{l}0.037 * * * \\
(0.002)\end{array}$ & $\begin{array}{l}0.010^{* * *} \\
(0.001)\end{array}$ & $\begin{array}{l}0.029 * * * \\
(0.002)\end{array}$ \\
\hline Tenure & $\begin{array}{l}0.029 * * * \\
(0.001)\end{array}$ & $\begin{array}{l}0.035^{* * *} \\
(0.001)\end{array}$ & & \\
\hline Age & $\begin{array}{l}0.005^{* * * *} \\
(0.000)\end{array}$ & $\begin{array}{l}0.005^{* * * *} \\
(0.000)\end{array}$ & & \\
\hline Medical coverage & $\begin{array}{l}0.025 * * * \\
(0.003)\end{array}$ & $\begin{array}{l}0.041 * * * \\
(0.003)\end{array}$ & $\begin{array}{l}0.029 * * * \\
(0.005)\end{array}$ & $\begin{array}{l}0.053 * * * \\
(0.005)\end{array}$ \\
\hline Constant & $\begin{array}{l}10.133^{* * *} \\
(0.014)\end{array}$ & $\begin{array}{l}10.012^{* * *} \\
(0.014)\end{array}$ & $\begin{array}{l}10.772^{* * *} \\
(0.083)\end{array}$ & $\begin{array}{l}11.579 * * * \\
(0.101)\end{array}$ \\
\hline Time dummies & Yes & Yes & Yes & Yes \\
\hline Demographics & Yes & Yes & Yes & Yes \\
\hline Observations & 33718 & 33719 & 33718 & 33719 \\
\hline R-squared & & & 0.702 & 0.693 \\
\hline $\begin{array}{l}\text { Number of } \\
\text { employees }\end{array}$ & 9516 & 9516 & 9516 & 9516 \\
\hline
\end{tabular}

Notes

Dependent variables are log of base salary and log of base salary plus bonus. Independent variables: Employee rating 0-4; Tenure: years in the sample; Age: in years; med cover: medical coverage $1=y e s, 0=$ no; Equations include are compensation grade level dummies; demographics are binary variables for sex, African American, Asian, Hispanic. 
Table 3: Employee job performance regressions

\begin{tabular}{llll}
\hline & Random effects & Fixed effects & Tobit (panel) \\
Log(profit per share) & $0.007^{*}$ & $0.013^{* * *}$ & $0.007^{*}$ \\
Log(salary + bonus) & $(0.004)$ & $(0.005)$ & $(0.004)$ \\
& $0.076^{* * *}$ & $0.036^{* *}$ & $0.075^{* * *}$ \\
Log(incentives) & $(0.008)$ & $(0.017)$ & $(0.008)$ \\
& $0.003^{* * *}$ & $0.002^{*}$ & $0.003^{* * *}$ \\
Tenure & $(0.001)$ & $(0.001)$ & $(0.001)$ \\
& $0.013^{* * *}$ & 0.000 & $0.013^{* * *}$ \\
Age & $(0.001)$ & $(0.000)$ & $(0.001)$ \\
& $-0.002^{* * *}$ & -0.003 & $-0.002^{* * *}$ \\
Medical cover & $(0.000)$ & $(0.002)$ & $(0.000)$ \\
& $-0.008^{*}$ & $-0.018^{* *}$ & $-0.008^{*}$ \\
Constant & $(0.004)$ & $(0.008)$ & $(0.004)$ \\
Observations & $0.229^{* * *}$ & $0.797^{* * *}$ & $0.235^{* * *}$ \\
Time dummies & $(0.087)$ & $(0.164)$ & $(0.085)$ \\
Demographics & 9386 & 9386 & 9386 \\
R-squared & Yes & Yes & Yes \\
Number of employees & Yes & Yes & Yes \\
\hline
\end{tabular}

Notes

Dependent variable is the firm's job performance rating of the employee at period $t+1$ (i.e. future job performance). Employee rating scaled in 0-4

Log profit per share: the value gained by the employee from exercising the option, calculated by deducting the non-qualified stock option grant (exercise) price from the stock price at exercise for every option exercised during a person-year. The result was then aggregated across all exercises in the year. In the table the gain is calculated on a per share basis.

Log(salary+bonus) is the log of base salary plus yearly bonus; Log(incentive) is the log of percentage of employee vested options. Tenure is years in the sample; Age is in years; med cover is medical coverage $1=$ yes, $0=$ no; All estimated models include job level level binary variables; demographics are indicator variables for gender, and the ethnicity are separate indicator variables coded for the following groups: African American, Asian, and Hispanic. 
Table 4: Employee job separations due to poor performance

\begin{tabular}{lll}
\hline & $\begin{array}{l}\text { Termination for poor } \\
\text { performance at } \mathrm{t}+1\end{array}$ & $\begin{array}{l}\text { Termination for poor } \\
\text { performance at } \mathrm{t}+1\end{array}$ \\
\hline & & \\
Log(profit per share) & $-0.045^{* * *}$ & $-0.011^{*}$ \\
& $(0.006)$ & $(0.008)$ \\
Log(Employee rating) & & $-0.160^{* * *}$ \\
& & $(0.019)$ \\
Log(salary + bonus) & 0.011 \\
Log(incentive) & $(0.007)$ \\
age & & $-0.011^{* * *}$ \\
& & $(0.002)$ \\
Medical cover & & $-0.002^{* * *}$ \\
& & $(0.000)$ \\
Observations & -0.008 \\
\hline
\end{tabular}

\section{Notes}

Dependent variable is Job separation at period $t+1$ for poor performance (i.e. future termination) $=1$ if terminated for poor performance; 0 otherwise. Poor performance examples are: Refused to perform job duties, Violation of company policy, Insubordination, Inability to perform job, Cash shortages, Falsification, Disciplinary action-suspension, Fraud, Theft etc.

Log profit per share: The firm's gift to the employee is the profit per share received by the executive. Option profit is the value gained from exercising the option, calculated by deducting the non-qualified stock option grant (exercise) price from the stock price at exercise for every option exercised during a person-year. The result was then aggregated across all exercises in the year. In the table the gain is calculated on a per share basis.

Log(salary+bonus) is the log of base salary plus yearly bonus; Log(incentive) is the log of percentage of employee vested options. Tenure is years in the sample; Age is in years; med cover is medical coverage $1=$ yes, $0=$ no; Equations include are compensation grade level dummies; demographics are binary variables for sex, African American, Asian, Hispanic. 
Table 5: Autocorrelation in profit per share

\begin{tabular}{lll}
\hline & Beta & t-ratio \\
\hline Number of individuals & & \\
Mean & 332 & 332 \\
Median & 0.417 & 1.408 \\
Min & 0.404 & 1.077 \\
Max & -0.547 & -2.581 \\
\hline
\end{tabular}

Notes

We estimated a simple linear regression model, $\mathrm{y}(\mathrm{t})=\mathrm{a}+\mathrm{by}(\mathrm{t}-1)+\mathrm{e}(\mathrm{t})$ for each employee separately in the database. Beta is the estimated value of b. The term y is profit per share. In the panel $t$ is quite short, so we estimated the model for individuals with 5, 6 or 7 observations only. The term b gives an estimate of the correlation of profit per share across time periods for each individual. Separate regressions were performed for each individual. 
Table 6: The relation between future profits per share and current job performance

\begin{tabular}{lll}
\hline & $(1)$ & $(2)$ \\
\hline Variables & Random effects & Fixed effects \\
Job performance (t) & -0.058 & -0.027 \\
& $(0.075)$ & $(0.091)$ \\
Log(salary+bonus) (t) & $1.463^{* * *}$ & 0.070 \\
& $(0.188)$ & $(0.338)$ \\
Tenure (t) & $0.790^{* * *}$ & \\
& $(0.025)$ & $0.360^{* * *}$ \\
Age (t) & $0.053^{* * *}$ & $(0.095)$ \\
& $(0.005)$ & -0.027 \\
Medical cover (t) & $-0.196^{* *}$ & $(0.147)$ \\
& $(0.090)$ & $-9.107 *$ \\
Constant & $-16.701^{* * *}$ & $(5.286)$ \\
& $(1.952)$ & 11,444 \\
Observations & 11,444 & Yes \\
Time dummies & Yes & Yes \\
Demographics & Yes & 0.481 \\
R-squared & - & 4297 \\
Number of employees & 4297 & \\
\hline
\end{tabular}

Notes

The dependent variable is the profit per share made by the employee on the sale of options in period $t+1$. Job performance is the firm's rating of the employee at time period t. Other variables defined in earlier tables. 
Table 7: Job performance evaluation regressions. Sample is for change in leadership year and for those individuals who leave the firm

\begin{tabular}{lll}
\hline & $\begin{array}{l}(1) \text { Estimated for the } \\
\text { CEO transition year }= \\
2006\end{array}$ & $\begin{array}{l}\text { (2) Estimated for the } \\
\text { employee departure year } \\
\text { and one year prior to that }\end{array}$ \\
\hline Variables & & \\
Log(profit per share) & $0.025^{* * *}$ & $0.035^{* *}$ \\
Log(salary + bonus) & $(0.009)$ & $(0.014)$ \\
& $0.087^{* * *}$ & $0.044^{*}$ \\
Log(incentives) & $(0.015)$ & $(0.025)$ \\
Tenure & 0.001 & -0.002 \\
& $(0.002)$ & $(0.003)$ \\
Age & 0.000 & -0.001 \\
& $(0.003)$ & $(0.006)$ \\
Medical cover & $-0.003^{* * *}$ & $-0.002^{* * *}$ \\
& $(0.000)$ & $(0.001)$ \\
Constant & -0.005 & -0.019 \\
Observations & $(0.007)$ & $(0.013)$ \\
R-squared & 0.114 & $0.540^{* *}$ \\
\hline$* * *$ p & $(0.157)$ & $(0.264)$ \\
& 2479 & 1217 \\
& 0.128 & 0.096 \\
\hline
\end{tabular}

*** $\mathrm{p}<0.01, * * \mathrm{p}<0.05, * \mathrm{p}<0.1$

Notes

Robust standard errors are in parentheses. Regressions contain controls for organizational levels, demographics, and year dummies (column 2). 


\section{References}

Adams, J. S. 1963: Toward an Understanding of Inequality, Journal of Abnormal and Social Psychology, LXVII, 422---436.

Akerlof, G. A. 1982: Labor Contracts as Partial Gift Exchange, Quarterly Journal of Economics, 97, 543-569

Akerlof, G. A., and J. L. Yellen 1988: Fairness and Unemployment, American Economic Review, Papers and Proceedings, 83, 44-49

Akerlof, G. A., and J. L. Yellen 1990: The Fair Wage-Effort Hypothesis and Unemployment, Quarterly Journal of Economics, 105, 255-283

Angrist, J.D. and J-S Pischke. 2010. The Credibility Revolution in Empirical Economics: How Better Research Design is Taking the Con out of Econometrics.” Journal of Economic Perspectives 24(2): 3-30.

Arkes, Hal R., Cynthia A. Joyner, Mark V. Pezzo, Jane-Gradwohl Nash, Karen SiegelJacobs, and Eric Stone (1994), "The Psychology of Windfall Gains," Organizational Behavior and Human Decision Processes, 59 (September), 33147.

Barber, B., T. Odeon, and N. Zhu. 2009 Systematic Noise. Journal of Financial Markets, 2009. 12: 547-569.

Becker, Howard. 1956 , Man in Reciprocity, New York: Prager.

Berkowitz, L. and Daniels, L.R. 1963. Responsibility and Dependency. Journal of Abnormal and Social Psychology, 1963, 66: 427-436.

Black, Fischer, and Myron S. Scholes, 1973, The Pricing of Options and Corporate Liabilities, Journal of Political Economy 81, 637-654.

Carpenter, J.N., Remmers, B., 2001. Executive stock options exercises and insider information. Journal of Business 74, 513-534.

Charness, G. 2004. Attribution and Reciprocity in an Experimental Labor Market. Journal of Labor Economics 22(3): 665-688.

Charness, G., G.R. Frechetter, and J.H. Kagel. 2004b. How Robust is Laboratory Gift Exchange? Experimental Economics 7(2): 189-205.

Core, J., Guay, W., 2001. Stock option plans for non-executive employees. Journal of Financial Economics 61, 253-287.

Croson, R.A., 2007. Theories of Commitment, Altruism, and Reciprocity: Evidence from Linear Public Goods Games. Economic Inquiry . 45(2): 199-216

Edmans, Alex, Xavier Gabaix, Augustin Landier. 2010. A Multiplicative Model of Optimal CEO Incentives in Market Equilibrium. Wharton School Working Paper. http://finance.wharton.upenn.edu/ aedmans/CEOIncentives.pdf 
Epley, Nicholas and Ayelet Gneezy (2007), "The Framing of Financial Windfalls and Implications for Public Policy,” Journal of Socio-Economics, 36 (1), 36-47.

Fama, Eugene F, 1997. Market Efficiency, Long Term Returns and Behavioral Finance, available at $\underline{\mathrm{http}: / / \mathrm{ssrn} . \mathrm{com} / \text { abstract }=15108}$

Fama, Eugene F, French, Kenneth R., 2010, Luck versus Skill in the Cross Section of Mutual Fund Returns, available at http://ssrn.com/abstract=13560, forthcoming Journal of Finance.

Fama, Eugene F. 1970. Efficient Capital Markets: A Review of Theory and Empirical Work. Journal of Finance 25 (2): 383-417.

Faulk, A., 2007, Gift Exchange in the Field. Econometrica, Vol. 75, No. 5 (September, 2007), 1501-1511

Fehr Ernst, Kirchsteiger G, Riedl A. 1993. Does fairness prevent market clearing? An experimental investigation. Quarterly Journal Economics 108:437-60

Fehr, E., E. Kirchler, A. Weichbold \& S. Gächter (1998), "When Social Forces Overpower Competition: Gift Exchange in Experimental Labor Markets,” Journal of Labor Economics 16: 324-351.

Fehr, Ernst, Goette, Lorenz, Zehnder, Christian, 2009, A Behavioral Account of the Labor Market: The Role of Fairness Concerns, Annual Review of Economics, 2009 vol. 1 (1) pp. 355-384

Ferrary, Michel. 2003. The Gift Exchange in the Social Networks of Silicon Valley.California Management Review. 45(4): 120-138.

Gneezy, U. and J.A. List. 2006. Putting Behavioral Economics to Work: Testing for Gift Exchange in Labor Markets Using Field Experiments, Econometrica, 74(5): 13651384.

Gouldner, Alvin W. 1960. The Norm of Reciprocity: A Preliminary Statement. American Sociological Review (25) 2: 161-178.

Gronau, Reuben. 1977. Leisure, Home Production, and Work-the Theory of the Allocation of Time Revisited. Journal of Political Economy (85): 1099-1124.

Hannan, L., J. Kagel, and D. Moser. 2002 Partial Gift Exchange in Experimental Labor Markets: Impact of Subject Population Differences, Productivity Differences and Effort Requests on Behavior." Journal of Labor Economics. 20:4.

Hannn, R. Lynn. Accounting Review; Jan2005, Vol. 80 Issue 1, p167-188, 22p

Heath, C., Huddart, S., and Lang, M. 1999. Psychological Factors and Stock Option Exercise. Quarterly Journal of Economics.

Hochberg, Y.H. and L. Lindsay. 2010. Incentives, Targeting, and Firm Performance: An Analysis of Non-executive Stock Options Review of Financial Studies. 23(11): 4148-4186. 
Huddart, S., Hughes, J.S., Levine, C.B., 2001. Public disclosure and dissimulation of insider trades. Econometrica 69, 665-681.

Huddart, Steven, “'Employee Stock Options,’’ Journal of Accounting and Economics,

Huddart, Steven, and Mark Lang, “'Employee Stock Option Exercises: An Empirical

Kagel, J., and A. Roth. 1995. The Handbook of Experimental Economics. Princeton: Princeton University Press.

Kranton, R.E. 1996. Reciprocal Exchange: A Self-Sustaining System. American Economic Review. 86(4): 830-851.

Krueger AB, Summers L.H. 1988. Efficiency wages and the inter-industry wage structure. Econometrica. 56:259-93

Leamer, E.E. 2010. Tantalus on the Road to Asymptopia. Journal of Economic Perspectives 24(2): 31-46.

Lee, D. and Rupp NG. 2007. Retracting a gift: How does employee effort respond to wage reductions? Journal of Labor Economics. 25:725-61

Lee, D.S. and T. Lemieux. 2010. Regression Discontinuity Designs in Economics. Journal of Economic Literature 48(2): 281-355.

List John. A., 2006. The behavioralist meets the market: measuring social preferences and reputation effects in actual transactions. Journal Political Economy 114(1):137

List, John A,, 2009. Social Preferences: Some Thoughts from the Field, Annual Review of Economics, 2009 vol. 1 (1) pp. 563-583

Malinowski, B. (1922). Argonauts of the Western Pacific: An Account of Native Enterprise and Adventure in the Archipelagoes of Melanesian New Guinea. George Routledge \& Sons, Ltd. .

Malkiel, B.G. 1996. A Random Walk Down Wall Street. New York: W. W. Norton

Mauss, M. (1990). The Gift: forms and functions of exchange in archaic societies. London: Routledge

Maximiano, S., Sloof, R., and Sonnemans, J. 2007. 1Gift Exchange in a Multi-Worker Firm Economic Journal. 117(522): 1025-1050.

O’Curry, Suzanne and Michal Strahilevitz (2001), "Probability and Mode of Acquisition Effects on Choices Between Hedonic and Utilitarian Options," Marketing Letters, 12 (1), 37-49.

Pruitt, D. G. 1968. Reciprocity and Credit Building in a Laboratory Dyad. Journal of Personality and Social Psychology. (8)2: 143-147.

Samuelson, Paul. 1973. Proof that Properly Discounted Present Values of Assets Vibrate Randomly. Bell Journal of Economics 4(2): 369-374. 
Shleifer, Andrei and Summers, Lawrence H. 1990. The Noise Trader Approach to Finance. Journal of Economic Perspectives. 4(2):19-33.

Sque, Magi and Payne Sheila A. 1994. Gift Exchange Theory: a critique in relation to organ transplantation. Journal of Advanced Nursing 19(1): 45-51.

Stanca, L. 2010. How to be Kind? Outcomes versus Intentions as Determinants of Fairness” (2010), Economics Letters, 106(1), 19-21

Steers, R. M., and L. W. Porter 1991: Motivation and Work Behavior (Fifth Ed.). New York: McGraw-Hill. 